\title{
Withdrawal of Care
}

\author{
J. Max Findlay
}

Can. J. Neurol. Sci. 2009; 36: 126-127

The CT scan looked bad. It showed a large right frontal and temporal hemorrhage with midline shift, blood in the subarachnoid cisterns, and lurking in the Sylvian fissure the spherical shadow of a middle cerebral artery aneurysm. The patient was lying just a few steps away from the computer screen in the neurointensive care unit, a thin, grey-haired woman in her mid-seventies, attached to a ventilator, and unresponsive due to the combined effects of her aneurysm rupture and our drugs. Her right pupil, which had been large and sluggish on arrival to hospital, was now equal to its opposite in size and briskly reactive, and her vital signs were stable for the time being. There was a background history of hypertension, mild diabetes and arthritis; I was told she collapsed while preparing dinner.

My new patient had immigrated with her husband to Canada from India six years prior, to live with a daughter and her daughter's family, where she prepared most meals and provided a good deal of child care so that both parents could work. There was another son in the city, and her eldest, another son, was en route from Toronto. None of this family or social information came from my neurosurgery resident who had admitted this lady during a fairly busy night in the emergency room and was now presenting her to me. Some came from the nurse and some I learned later. I am forever hopeful that my immediate enquiry into these matters will in itself underscore their importance in situations like these, so I decided not to comment and possibly embarrass my resident. He's a good resident, and not much is lost on him.

I recall presenting a similar patient to one of my surgeon teachers, decades ago, the hard-copy CT images cruder but no less ominous. A very senior surgeon who we all deeply respected, he listened intently from his seat in the surgeon's lounge, asked a few questions, and after extinguishing his cigarette in the ash tray at his side, trained his eyes on mine, and simply said "Max, this patient is not going to do very well." I was his senior resident. He left the rest up to me.
Between then and now, I have had a good deal of experience of my own, including that gained as a young and aggressive surgeon from which I learned that patients like this might survive surgery and possibly even hospitalization under my care, but still, "they do not do very well". I had decided that I was not going to try to fix that CT scan and not try to fix this person. It was not a happy decision.

One way of approaching families under these circumstances is to feign procrastination, telling them that you are waiting for "stabilization", or clear signs that the patient is savable, before proceeding to aneurysm repair. In truth you have decided in your heart not to treat "aggressively", and instead you are biding time, keeping loved ones in limbo and with deteriorating hope, waiting for the inevitable aneurysm rerupture, or heart attack, or pulmonary embolus, or fulminating sepsis to put an end to things. It can take a long time. Now in some situations, with some neurosurgical illnesses and in some patients, this is exactly the right approach and just what we do. But with those patients, in those situations - unlike this one, the "wait and see" is not phony, and we are not keeping the family in the dark about anything. It is we, the doctors, who are in dark. With those patients we really do need more time to know.

The second way of dealing with the situation I faced with my new patient is harder, and that is to make it clear to them from the very beginning everything we know, and that is that their loved one cannot survive this catastrophe, despite all and best efforts. We will not be doing any further invasive investigations, and we will not repair the aneurysm, now or ever. To this tragedy-struck family we introduce the idea of withdrawal of care.

The family meeting was difficult as expected. Questions immediately arose as to why we were not operating - just what were we doing? Anguish, guilt, fear, disbelief, distrust - a symphony of emotions to expect and respond to. This new

From the Division of Neurosurgery, Department of Surgery, University of Alberta, Edmonton, Alberta.

Received October 30, 2008. Final Revisions Submitted November 3, 2008.

Correspondence to: J. Max Findlay, Division of Neurosurgery, Department of Surgery, University of Alberta, 2D102 Mackenzie Center, 8440, 112 Street, Edmonton, Alberta, T6G 2B7, Canada. 


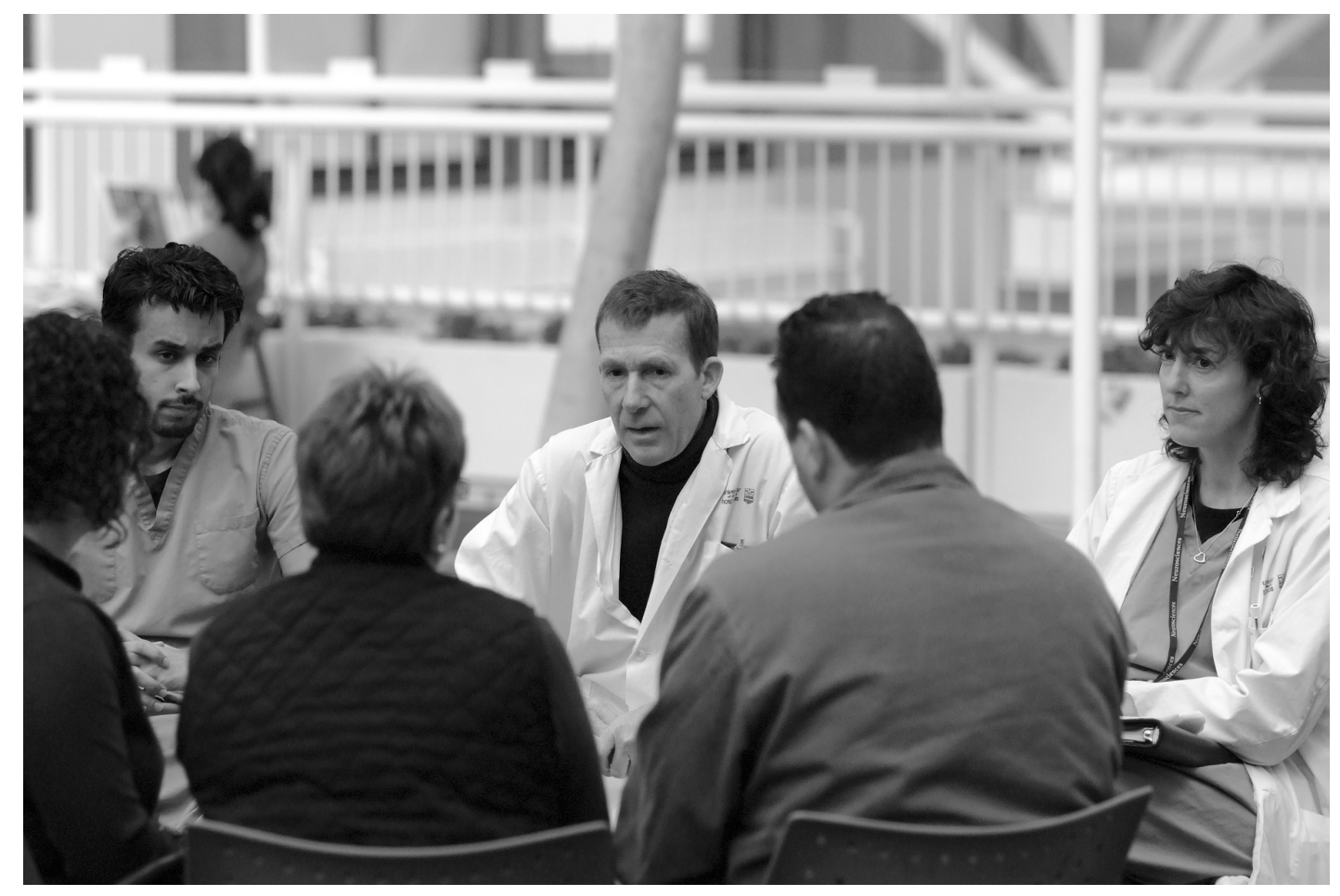

Photo courtesy of Stephen Wreakes

patient of mine was a much-loved mother and grandmother who contributed significantly to her family's day-to-day life. There was a great deal they needed to tell me before treatment decisions were made! From my side there was essential information to communicate and repeat. I went over the CT scan with them, allowing them to see with their own eyes the damage done. As much as we all wished otherwise, she could not get better and return to who she was. Explaining that withdrawal of care is a medical decision, something they must understand and accept before we proceed, but not something they are responsible for. We would never take their mother off the ventilator against their wishes. We would not rush things and we could wait. She is not brain dead-she will continue to breathe and her heart continue to beat after the endotracheal tube was removed. But she would eventually die. We can't guess how long it will take. We would ensure she was kept comfortable. Meet their eyes, never show frustration, and ask for questions. Bad news - too much and too soon, and no way around it.

The next morning there was no change in my patient's condition, and another round of questions from her family. Her husband, a tall, stately, turbaned man with a flowing grey beard, finally spoke.

My patient was fortunate to be transferred to a private room on a regular ward in the hospital-pure luck. Orders were written for "compassionate care". There was ample room for her grieving family and visitors. So much is up to the nurses at times like this. I visited each day briefly, something over the years I have had to discipline myself to do in situations like this. No happy, grateful faces that doctors on rounds look forward to. Just a grim acknowledgment and another "how long?". The answer is always the same: "days, eventually hours, but not weeks..

My patient passed away on a Sunday night, four days after extubation. Monday morning there was a death certificate to fill out so that the body could be released, and a discharge summary to dictate. After I was finished with those I left a brief sympathy message for my patient's son on his cell-phone when he did not pick up. Doctors want to be loved by their patients, and sometimes they just don't want to be hated by their patient's families. 